УАK (UDC) 141.319 .8

DOI: 10.26565/2226-0994-2019-61-1

Nataliia Zahurska

\title{
FROM NARCISSISM TO AUTISM: A DIGIMODERNIST VERSION OF POST-POSTMODERN
}

In this article the causes and features of a shift from neurosis to narcissism and then autism were investigated. Moreover, special attention is paid not so much to the psychological or even psychiatric aspects of the problem, but to changes in the general features of a human being. Thus, when speaking of the transition from narcissism to autism, one is focusing on true autism, which is characterized by veracity, sincerity and authencity, which reveal themselves in the form of a special kind of infantility, a kind of mature infantility. A suitable example of such infantility is found in the animated film Shrek, a certain barbarism of which is not so ironic or even knowing ironic, but to a greater extent it is warm, earnest and serious although childish. Among other infantile practices, it is worth noting the situationalistlettrist practice of organizing a text in the form of an $\mathrm{ABC}$ alphabet book, a hornbook, which is actualized in a digimodern context. True autism and to some extent pseudoautism in a certain sense become a way to cope with the trance and amnesia of pseudomodernism and leave a hope for the future. Thus, paradoxically, wholeness that was lost is restored through desocialization and sociopathy. This article also draws parallels between digimodernism and speculative realism, conceptualization of interpassivity as well as automodernity. It is emphasized that personal autonomy and automation can be achieved through the use of devices as a means of achieving productive loneliness, which should be distinguished from alienation. In this case, the widespread use of sensory experience as a way of communication is especially important, as an example of which Hope Sandoval's mode of being and work are considered. It suggests that the high-tech/high-touch approach is best released in DIY activities. The above considerations allow to conclude that true autism is one of the most actual post-postmodern modes of subjectivation.

Keywords: digimodernism, pseudomodernism, post-postmodern, technological realism, narcissism, true autism.

Many researchers such as L. Hutcheon, M. MacLuhan, G. Lipovetsky, S. Žižek, A. Zupančič, I. Smirmov, A. Kirby and others draw attention to the fact that in a postmodern conditions neuroticism becomes much less common than perversity, first of all narcissism and autism. These considerations determine the relevance of this study. L. Hutcheon stresses precisely literature narcissism, which is inherent to narcissistic postmodern textuality and the textualized postmodern condition as a whole. "Narcissistic' - the figurative adjective chosen here to designate this textual self-awareness-is not intended as derogatory but rather as descriptive and suggestive, as the ironic allegorical reading of the Narcissus myth which follows these introductory remarks should make clear" [Hutcheon, 1980, p. 2]. This narcissism is enhanced through paradoxal metafictionality, which provides appellation to the problem of what fiction that-is.

Then G. Lipovetsky proposes to designate what narcissistic postmodernity and postmodern mean on the whole. "All over this is the disappearance of the heavy real, it is the desubstantialization, ultimate figure of the deterritorialization, which orders postmodernity" [Lipovetsky, 1986, p. 17]. Such an approach is evolving in a context of hypermodern by G. Lipovetsky as a version of postmodern. In addition, it is easy to sight that the thus understood narcissus correlates with the deterritorialized narcissistic schizo of J. Deleuze and F. Guattari. But G. Lipovetsky notes that postmodern narcissism isn't an alienation or even entertainment so far as it appears as an epidermal, tactile apathy and indifference irreconcilable with a something tragic. Nevertheless, action of this kind of narcissism assumes rather an action rather than a substance and becomes rather a mirror itself rather than a reflection. Thus, the aim of this study is to track the causes of these changes and the tasks of their features.

(C) Zahurska N. V., 2019.

(cc) BY This is an open-access article distributed under the terms of the Creative Commons Attribution License 4.0. 
When considering A. Nusselder's meaning of narcissism, one notes that he refers back to lacanianism. "Media are thus, in a Kantian-Lacanian way, necessary instruments to synthesize the multiple stimuli of the senses. <..> Narcosis as (Second) Nature' (to paraphrase McLuhan)" [Nusselder, 2009, p. 140-141]. In this case Narcissus appears as an anesthetized Narcosis just like an embodiment of anesthesis instead of A. Badiou's inaesthetics. It is an e(s)th(et)ics, esthetics and ethics of mode of being at the same time. It arises from a postmodern artifice (parody, allegory, mise en abyme, etc.) using L. Hutcheon's concept. She discerns the passage of artifice in baroque and neobaroque, which relates to the research of W. Benjamin and G. Deleuze, who focus their attention on the baroque superfolding of subjectivation. An artifice, if it is examined in this way, is not so much a phantasm, a figment of the imagination or something else that can be only be a warp of an artifice, but instead it is "linguistic artifice, inter- and intra- textuality, and narrative mirroring" [Hutcheon, 1980, p. 2].

Referring to the research of H. Pagels, $\mathrm{H}$. van den Boom and Debra B. Bergoffen, A. Nusselder passages from media and mediacy on the whole to immediate analogous sight and immediacy on the whole. He compares the immediacy of reality to J. Lacan's eluding real and stresses a necessity to grasp it rather than to simulate it. Such an approach can be considered as the premise for A. Kirby's Technological Realism. In his opinion, technology changes life to annihilation, if we refer back to N. Land's concept, and Digital Modernism by A. Kirby. Addressing the latest trends determines the novelty of the problems considered in this study.

A digit here is understood not only as a unit of digitized information, traversals of technology and textuality, but also as a thumb. With it Thumbelina (in French Petite Poucette) as an embodiment of a post-postmodern human operates with a touch screen, which often boils down to all its sensitivity and sensibility at once. "Thumbelina lives in a composite tapestry and covers her space with a disparate marquetry. Her eyes are fascinated by this kaleidoscope, and her ears ring with a confused chaos of voices and sensations that foreshadow other reversals" [Serres, 2015, p. 60]. She no longer appears in the same space; she is like an atom when it has no valence and she is all naked. However, M. Serres surmises that hominescence as humanizing transformations, the processuality of humanity and becoming a human today are revealed precisely in the concept-image of the Thumbelina operating with sensors. This fundamentally infantile female is contrasted with the male as animally active, inherent in modern or even postmodern.

Deepening the degree of problem development, M. Serres asserts that it is worth learning from millennials so as not to be out of date. On the other hand, A. Kirby is not tuned in such a positive way and he associates digimodernism and pseudomodernism with such qualities as ignorance, fanaticism and anxiety. Such a situation develops due to the place that postmodern irony occupies regarding trance and amnesia. "Here, the typical emotional state, radically superseding the hyper-consciousness of irony, is the trance - the state of being swallowed up by your activity" [Kirby, 2006].

If the quotation of postmodern appeals to the past, digimodernism as a post-postmodern trend is oriented toward the clear present and also leaves no hope for the future: "... our gaze turns backwards ever more frequently in an attempt to take stock and to assess where we stand in the course of time. Simultaneously, however, there is a deepening sense of crisis often articulated in the reproach that our culture is terminally ill with amnesia" [Huyssen, 1995, p. 1]. If $\mathrm{F}$. Jameson claims postmodern as a way of playing with residual and emerging forms, digimodermism has a liquid, blurred, fuzzy limits and boundaries. Furthermore, due to hidden moderation, hierarchization is carried out, which restricts the will to creation of the schizonarcissus.

Due to such a changes of feelings and thinking, according to A. Kirby, a surface without a depth as a force field instead of any ideology is created. Thus, the value of any text is distinct according to its onwardness, haphazardness, evanescence, reformulation and intermediation of textual roles. Moreover, it is anonymous and has multiple and social authorship; it is also fluid-bounded text and electronic-digitality. It appears as an endless narrative, when any 
information is available, but none is interesting because although it does not become obsolete, it also does not recover. When a subject is aware of its situation in the space of objects "in place of the neurosis of modernism and the narcissism of postmodernism, pseudo-modernism takes the world away, by creating a new weightless nowhere of silent autism. You click, you punch the keys, you are 'involved', engulfed, deciding. You are the text, there is no-one else, no 'author'; there is nowhere else, no other time or place. You are free: you are the text: the text is superseded" [Kirby, 2006]. This silent autism, which A. Kirby defines as pseudoautism, is compared to autism as a psychic disorder, which has physiological nosology. The weightless nothingness of pseudoautism is first and foremost found now first of all in Instagram as the best embodiment of digimodernism.

In spite of Instagram and other social network's display of streams, food porn, etc. by inserting ordinary real life into a digital social context, A. Kirby insists that on the whole it comes across instead as desocialization and sociopathy. In addition, he notes that despite the fact that digimodernist conditions are usually considered as a way for everyone to become an author, in fact the true death of the author is coming. Pseudomoderm doesn't even suggested the possibility for everyone receiving 15 minutes of fame, as A. Warhol claimed. When everyone is a famous author, no one is an author at all.

A. Kirby stresses one more important feature of digimodernism - its infantility. With such a kind of infantility often can reanimates veracity, sincerity, authenticity, and even normalcy can be achieved instead of postmodern illegibility and indiscrimination by adhering to the mindset that "anything goes". On the whole it can be descried as appearing as a type of reality passion that is inherent in post-postmodern philosophy and culture. "A tissue of detourné quotations, nostalgia and irony, these shorts display above all a joyous and dazzling universality: they appeal to and satisfy both small children and jaded adults (and overconceptual theoretists) in a postmodernism as natural and inevitable, as unstrained and as free as breathing. This form of postmodernism as pure entertaiment for all the family bears witness on one level to the total permeation of society by a contemporary cultural movement, but on another level this mixture of sophisticated self-awareness and generous fun suggests the movement has nowhere left to go" [Kirby, 2009, p. 11]. Thus, post-postmodern is, in this sense, a version of postmodern, insofar as such infantility can be interpreted as a version of double coding by U. Eco.

Among the numerous examples of digital animation, the most revealing seems to be Shrek by A. Adamson and W. Jenson. The plot of this movie has to do with love, which is quite in the post-postmodern spirit of reanimation of love instead of exaggerating the significance of sexuality. However, the attitude towards love in Shrek is ironic and even barbaric due to the use of infantile jokes below the belt. When Shrek begins, there is a voice-over about enchantment, from which love's first kiss must free a princess. Upon hearing this, Shrek exclaims, "Like that's ever gonna happen! What a load of-." "An ogre emerges from a flushing toilet, his ass presumably wiped clean on the story" [Kirby, 2009, p. 12]. But finally, it was Shrek, not Prince Charming, who was too preoccupied with increasing his charm with the help of some advertised funds, who saved Princess Fiona. According to A. Kirby, such a barbarism is not very ironic or even knowing ironic, but to a greater extent it is warm, earnest and serious, although childish. It can even be assumed that in post-postmodern society, seriousness and sincerity can only be found in an autistic child as the embodiment of a post-postmodern human being.

Thus, true autism is contrasted with pseudo-autism, which also means a certain set of experiences, and not clinical autism. Therefore, since it comes about a fairly broad autistic spectrum of culture, autism has turned into a linguistically convenient umbrella term. Nevertheless, A. Kirby prefers true autism, highlighting primarily the ability of autists to solve the most complex problems. If pseudoautism assumes, due to frivolity, hypersensitivity, ignorance, problems with concentration, complacency and empty tolerance in the presence of a large amount of live communication, desocialization and incompetence, true autism in this case makes it possible to live a full life, albeit with disabilities. Perhaps that's why A. Kirby himself ended his activities on Twitter aka@Digimodernist. 
In a similar way R. Samuels differentiates a certain traversal aspects of techné and autism. They refer an entire environment, in which a personal autonomy and automatization through devices are inseparable on their own. It seems, therefore, that this is the main contradiction of a current life today when automized communication, which does not leave human beings the possibility of at least a temporary stay in productive loneliness, leads to situational autism. "Here, individual autonomy is seen as something that has to be constantly negotiated and revised, and is thus not a finished product, and this conception of subjectivity feeds into the social definition of postmodernity" [Samuels, 2008, p. 224]. R. Samuels designates such a junction as an automodernity, which, however, is compatible with multiculturalism, social constructivism, esthetic and academic postmodernity. In every case the construction of subjectivity as a selfhood refers, to a large extent, to what is imagined and often neglects psychological and even anatomical features. In a certain sense they are provided by objects, which allows correlates automodernity with object-oriented ontology. In addition, it significantly aligns with S. Žižek's conception of interpassivity, which assumes a passive subject and active object. "In the case of automodernity, I will be arguing that the power of new automated technologies to give us a heightened sense of individual control often functions to undermine the awareness of social and cultural mediation, and this lack of awareness can place the isolating individual against the public realm" [Samuels, 2008, p. 225]. A subject in such a case receives negative freedom, i.e. the freedom not to do something instead of a positive and creative freedom, which is associated with this autistic alienation.

In a certain sense, this alienation is also quite infantile. Positive freedom is realized in children's practices, among which linguistic ones stand out. If G. Deleuze creates a situationalist, lettristic alphabet, composed of letters, then A. Kirby creates the antilexicon of early digimodernism. The nihilism of this alphabet immediately brings to mind the most important circumstance of psychoanalytic practice. If a patient who is trying to interpret his own dream, claims, "it is definitely not...", Freudianism suggests that this is the most exact interpretation of the dream. Thus, when A. Kirby claims, "A is not exactly for Author", he again raises the problem of authorship in connection with true autism. "P isn't for Passive (and Active is in trouble, too)," first and foremost the second part, also seems especially interesting, since it can be correlated with the understanding of interpassivity by S. Žižek.

The considerations expressed in " $\mathrm{L}$ is sort of for Listener" are also extremely important. A. Kirby distinguished between two kinds of them with two varying intensities and grammars of listening with the supposition of an answer and without such a supposition. But the listener reacts in any case even if, as in the second case s/he isn't actually listening closely. In this case the reaction is implicit and autistic because the appellation just is absent to the listener. To save autistic implicit intimacy is a way to awoid dangerous sociable illusions of straight lines, Skype conferences and the like with extimate outputs.

An exellent example of autistic implicit intimacy is the singing and demeanor of elusive Hope Sandoval, who is a very shy and private person and always feels nervous and awkward on a stage and during an interviews and she is refuging behind curtains of hair and curling in on herself. This is why journalists proclaim, that interviews with Hope Sandoval were the worst interview they had ever done, because she was answered every question as if she were revealing her underwear in squirms. In interview with C. McLean Hope Sandoval directly declares "I want to be alone", trying to hide in sight "Cat got your tongue? No, Hope Sandoval just prefers to sing" [Sandoval, 2001]. Additionally, it is often quite difficult to recognize, clarify and understand the lyrics of her songs, as she speaks briefly in monosyllables, interjections with long pauses or, on the contrary, she omits them and other extraneous words. It is possible to consider such behavior as one of the tactics for exercising the right to silence in the foucauldian sense.

Hope Sandoval refused to meet even with Massive Attack while recording Paradise Circus and worked in her studio: "It's better in a way. You don't have so much anxiety. (It's hard singing) with somebody you don't know. It's more free, more private on your own" [Sandoval, 2001]. It sounds like the lyrics from her song Beautiful Seed (2016): 
But tinkers and tailors and soldiers unknown,

Nobody could keep this lady their own.

$<\ldots>$

Hey little lady, I'll give you something.

You'll never forget me, and the oceans will say...

It also remains unknown how she responded to the ocean, whether she responded at all and into whom she could fades away in the vein of true autism. Hope Sandoval doesn't even attaches a meaning to the long-awaited release of her album, because she simply doesn't hurry by default. Such an artists don't try to steer through stir. As a result, with the help of her whisperinggrass voice she conveys extremely intimate tenderness and fragile sensibility, realizing a true autistic tactic and skipping the surface without any depth: "'Mmm, it got a bit awkward after a while,' she murmurs, 'because it just starts to become a sort of shallow, you know" [Sandoval, 2001]. However, without hiding behind quotes as a postmodernists she doesn't across as apathetic or joyless, but rather as really singularly motivated. "Whereas postmodernism called 'reality' into question, pseudo-modernism defines the real implicitly as myself, now, 'interacting' with its texts" [Kirby, 2006], post-postmodernists quietly creates what is real.

J. Naisbitt, who suggested a high-tech / high-touch approach, also attaches great importance to art as well as to post-secular religion, alternative medicine, home-made items, real games and even bird watching. In this way the problematization of empathy and eupathy is being renewed and sensory deprivation, which is caused by technology, is overcome. It should be noted that technology that contributes to our humanness is also used. In this instance an art appears not as an artifice, but as a real activity and preserving "a high touch balance, a human ballast" [Naisbitt, 2001, p. xiv]. A good example of delivering a high-touch message through high-tech media is seen in history of Martha Stewart, who widely disseminates the technics of DIY (Do It Yourself) activities: "Her message is high touch; her medium is high tech. If the medium is the message, Martha is shifting to high tech" [Naisbitt, 2001, p. 50]. In this way true autism in a living, true reality isn't isolated, but rather rallies through advanced simplicity.

In conclusion, it is important to stress that such an intellectual trend as digimodernism demonstrates a certain features, properties and qualities of post-postmodern eventuality, which relate primarily to "human, all too human". This is why a stable critical approach to the conceptualization of digital is nessesary. However, thanks to the comprehension and practice of digital autism the possibility of the emergence and conceptualization of true autism as a mode of subjectivation appears. In the course of the shift from infantile narcissism to infantile autism, the modes of reanimation of the earnestness, sincerity and truthiness of human beings are outlined.

\section{REFERENCES}

Hutcheon, L. (1980). Narcissistic Narrative: The Metafictional Paradox. Waterloo, Ontario: Wilfrid Laurier University Press.

Huyssen, A. (1995). Twilight Memories: Marking Time in a Culture of Amnesia. N.-Y.: Routledge.

Kirby, A. (2009). Digimodernism: How New Technologies Dismantle the Postmodern and Reconfigure Our Culture. New-York: Continuum Publishing Corporation.

Kirby, A. (2006). The Death of Postmodernism and Beyond. Philosophy Now, 58. Retrieved from https://philosophynow.org/issues/58/The_Death_of_Postmodernism_And_Beyond.

Lipovestsky, G. (1986). Narcisse ou la Stratégie du Vide. Réseaux, 4 (16), Philosophie et Communication, 7-41.

Naisbitt, N., Philips, D., \& Naisbitt, J. (2001). High Tech/High Touch: Technology and Our Accelerated Search for Meaning. L.: Nicholas Brealey Publishing.

Nusselder, A. (2009). Interface Fantasy: A Lacanian Cyborg Ontology. Cambridge, MA: MIT Press.

Samuels, R. (2008). Auto-modernity after Post-modernism: Autonomy and Automation in Culture, Technology, and Education. In T. McPherson (Ed.), Digital Youth, Innovation, and the Unexpected (pp. 219-240). MA: The MIT Press. 
Sandoval, H. (2001, October 11). I Want to Be Alone. An Interview by Craig McLean. The Telegraph: The Official Website. Retrieved from https://www.telegraph.co.uk/culture/47 26021/I-want-to-be-alone.html.

Serres, M. (2015). Thumbelina: The Culture and Technology of Millennials. L.; N.-Y.: Rowman \& Littlefield International.

\section{Zahurska Nataliia V.}

D.Sc. in Philosophy, Professor of the Department of Theoretical and Practical Philosophy named after Professor J. B. Schad

V. N. Karazin Kharkiv National University

6, Svobody sqr., 61022, Kharkiv, Ukraine

E-mail: zagurskaya@karazin.ua

ORCID: http://orcid.org/0000-0001-5142-8064

Article arrived: 04.11.2019

Accepted: 20.12.2019

\section{ВІА НАРЦИСИЗМУ АО АУТИЗМУ: АІАЖИМОАЕРНІСТСЬКА ВЕРСІЯ ПОСТ-ПОСТМОАЕРНУ}

\section{Загурська Наталія Віталіївна}

Аоктор філософських наук, професор кафедри теоретичної і практичної філософії імені професора Й. Б. ШаАа

Харківський національний університет імені В. Н. Каразіна

м. Свободи, 6, Харків, 61022

E-mail: zagurskaya@karazin.ua

ORCID: http://orcid.org/0000-0001-5142-8064

У статті були вивчені причини та відмітні ознаки зсуву віА неврозу до нарцисизму й потім Ао аутизму. Водночас було приділено спеціальну увагу не стільки психологічним аб̆о навіть психіатричним аспектам проблеми, скільки змінам у загальних відмінних ознаках Аюдської істоти. Так, говорячи про перехіА віА нарцисизму до аутизму, сліА розуміти, що тут наразі йдеться про так званий істинний, «трушний» аутизм, який характеризується Аостовірністю, щирістю й автентичністю, що прояв яють себе в особливій інфантильності або ж, так би мовити, у «зрілій інфантильності». ВіАповіАний приклаА такої інфантильності виявляеться в анімації «Шрек», оскільки певне варварство головного героя цієї анімаційної стрічки е не стільки іронічним або навіть «познавально іронічним», але більшою мірою теплим та серйозним (хоча й серйозним по-дитячому). Серед інших інфантильних практик варто віАзначити сітуаціоністсько-леттрістську практику організації тексту у формі абетки, алфавіту, що актуалізується в АіАжимодерному контексті. Істинний аутизм, псевдоаутизм у певному сенсі стає способом впоратися з трансом i амнезією псевдомодернізму, залишаючи надію на майбутнє. Так парадоксальним чином втрачена цілісність віАновлюється за допомогою Аесоціализації та соціопатії. У статті також проведені паралелі між діАжимодернізмом і спекулятивним реалізмом, концептуалізацією інтерпасивності, а також аутомодернізмом. ПіАкреслюється, що персональна автономія і автоматика можуть бути реалізовані за Аопомогою Аевайсів як засобів Аосягнення продуктивної самотності, яку сліА віАрізняти віА відчуження. У цьому разі особливо важливим є широке використання сенсорного АосвіАу як способу комунікації, прикладом чого можуть бути творчість і модус існування Хoyn Сандовал. Це передбачає, зокрема, що хай-тек / хай-тач піАхіА найкращим чином реалізується у DIY (англ. Do It Yourself - Зроби Сам) активності. Наведені міркування дозволяють зробити висновок про те, що істинний аутизм є оАним з найбіАьш актуальних постпостмодерних модусів суб̆'ективації.

КАючові слова: АіАжимодернізм, псевдомодернізм, постпостмодерн, технологічний реаАізм, нарцисизм, істинний аутизм. 


\section{ОТ НАРЦИССИЗМА К АУТИЗМУ: АИАЖИМОАЕРНИСТСКАЯ ВЕРСИЯ ПОСТ-ПОСТМОАЕРНА}

\section{Загурская Наталья Витальевна}

Аоктор философских наук, профессор кафедры теоретической и практической философии имени профессора И. Б. Шада

Харьковський национальный университет имени В. Н. Каразина

пл. Свободы, 6, Харьков, 61022

E-mail: zagurskaya@karazin.ua

ORCID: http:/ /orcid.org/0000-0001-5142-8064

В статье были изучены причины и отличительные признаки сдвига от невроза к нарциссизму и затем к аутизму. Кроме того, было уделено специальное внимание не столько психологическим или даже психиатрическим аспектам проблемы, сколько изменениям в общих отличительных признаках человеческого существа. Так, говоря о переходе от нарциссизма к аутизму, имеется ввиду так называемый истинный, «трушный» аутизм, характеризующийся Аостоверностью, искренностью и аутентичностью, которые проявцяют себя в особого рода инфантильности или же, так сказать, «зрелой инфантильности». Подходящий пример такой инфантильности обнаруживается в анимации «Шрек», поскольку определенное варварство главного героя этого мультфильма не столько иронично или даже «познающе иронично», но в большей степени тепло, серьёзно и важно (хотя и важно по-Аетски). СреАи Аругих инфантильных практик стоит отметить ситуационистски-леттристскую практику организации текста в форме азбуки, алфавита, который актуализируется в АиАжимодерном контексте. Истинный аутизм, псевдоаутизм в определеном смысле становится способом справиться с трансом и амнезией псевдомодернизма и оставляет надежду на будущее. Так парадоксальным образом утраченная целостность восстанавливается посредством десоциализации и социопатии. В статье также проведены параллели между АиАжимодернизмом и спекулятивным реализмом, концептуализацией интерпассивности и аутомодернизмом. Подчеркивается, что персонаАьная автономия и автоматика могут быть реализованы посредством девайсов как средств Аостижения продуктивного одиночества, которое следует отличать от отчуждения. В этом случае особенно важно широкое использование сенсорного опыта как способа коммуникации, в качестве примера которого могут быть рассмотрены творчество и модус существования Хоуп Сандовал. Это предполагает, что хай-тек / хай-тач подхол наилучшим образом реализуется в DIY (англ. Do It Yourself - САелай Сам) активности. Упомянутые соображения позволяют сделать вывод о том, что истинный аутизм явАяется оАним из наиболее актуальных постпостмодерных модусов субъективации.

Ключевые слова: Аилжимодернизм, псевдомодернизм, постпостмодерн, технологический реализм, нарциссизм, истинный аутизм.

Статья поступила в редакцию: 04.11.2019

Утверждена к печати: 20.12.2019 